Check for updates

Budapest, Hungary

katakarath@gmail.com

Cite this as: BMJ 2020;370:m3543

http://dx.doi.org/10.1136/bmj.m3543

Published: 15 September 2020

\section{Covid-19: How does Belarus have one of the lowest death rates in Europe?}

Plagued by political turmoil over "Europe's last dictatorship" and with a president in denial of covid-19,
how has Belarus ended up with one of the lowest death rates on the continent? Kata Karáth reports Kata Karáth

Belarus's beleaguered government remains unfazed by covid-19. President Aleksander Lukashenko, who has been in power since 1994, has flatly denied the seriousness of the pandemic, refusing to impose a lockdown, close schools, or cancel mass events like the Belarusian football league or the Victory Day parade.

Yet the country's death rate is among the lowest in Europe-just over 700 in a population of 9.5 million with over 73 ooo confirmed cases.

\section{Pandemic mindset}

The relatively low death rate is thought to be thanks to Belarus's large hospital capacity which allowed the country to isolate people early on, says Andrei Vitushka, a healthcare policy expert at the Belarusian Institute for Strategic Studies in Vilnius, Lithuania.

With 11 hospital beds per 1000 people, Belarus outnumbers nations like Germany (8) or the UK (2.5). ${ }^{1}$ "It's usually a problem because it takes a lot of money to maintain them, but it turned into our advantage in this situation," says Vitushka, who is also an intensive care physician in Belarus.

"Belarus, like most of the post-Soviet states, has a focus on "sanitary epidemiological problems" meaning large scale health scares like a pandemic," says Rasmus Nilsson, a teaching fellow at University College London's school of Slavonic and east European studies.

This may be one reason Belarus also outperformed most of Europe in terms of mass testing during the first four months of the pandemic. While many countries were reluctant to carry out extensive testing, according to the state owned news agency BelTA, testing in Belarus started as early as 23 January. Most kits were donated or purchased from China and Russia ${ }^{2}$ using government funds and donations from companies ${ }^{3}$ and ordinary citizens. ${ }^{4}$ The country stepped up testing in early April, 5 developing its own rapid testing kits ${ }^{6}$ and switching to the use of domestically produced reagents for polymerase chain reaction testing in May. ${ }^{7}$ According to government information, there are now 32

laboratories processing samples across the country and testing is widespread in hospitals as well as from GPs.

By the end of June, Belarus had conducted around one million tests, ${ }^{8}$ covering more than $10 \%$ of its population.

\section{Citizens doing it for themselves}

With low expectations of the authorities, Belarusians were bracing themselves for the worst. ${ }^{9}$

With the last of a handful of press briefings on the pandemic held on 24 April, information on safety protocols and the country's situation has been scarce, inconsistent, and often contradictory. "It's a personal decision for every citizen. If you want, you wear a mask. If you don't want to, you don't wear a mask-and this is a problem," says Vitushka.

Citizens began practising self-isolation early on. On 26 March a crowdfunding campaign "ByCovid19" was launched in order to buy safety equipment for hospitals across the country. The movement collected around \$360 o00 (£277 000; €304 000) in three months and, with the help of nearly 1500 volunteers, they purchased and distributed around 450000 pieces of personal protective equipment, oxygen tanks, and other medical equipment.

Although initially slow to react, the health ministry has worked alongside ByCovid19 and taken measures to reorganise hospitals and encourage social distancing, says Vitushka.

Another factor is that Belarus has very few care homes (203 beds per 100000 of the population compared with 854 in the UK), with most elderly citizens living separately. ${ }^{10}$ This has helped shield its most vulnerable. "In many cases in Belarus, you have already had some isolation of elderly people, particularly in the countryside or in single flats" says Nilsson.

Nilsson says Belarus also benefited from being a relatively isolated country where the government can easily shut down borders and monitor those passing through. "People tend to go in the other direction," he says, "Very few people will go to Belarus for holidays or work."

\section{Not out of the woods}

With anti-government demonstrations ongoing in Minsk and other big cities following a controversial 9 August election that awarded Lukashenko another term, Belarus will likely see a sudden spike in infections. Nilsson believes this will serve as another pretext to crack down on government critics.

Lukashenko has allegedly overcome coronavirus infection, Nilsson says, framing it as yet another chapter in Belarus's historical sufferings that the country managed to overcome. "This is Lukashenko 101 , and he is probably not going to change." 
Although the low death numbers are encouraging, some experts fear that many coronavirus related deaths are registered as cases of pneumonia-UN data show a difference of 5605 between April-June 2019 compared with the same period in 2020. ${ }^{11}$ And the deaths per capita ratio remains one of the highest in Europe. Nilson is cautious, "Until we have the figures for excess deaths, I don't want to praise Belarus too much.”

\section{Commissioned, not peer reviewed.}

Competing interests: I have read and understood BMJ policy on declaration of interests and have no relevant interests to declare.

Fullfact. Do we have fewer hospital beds than most of Europe? 17 April 2014. https://fullfact.org/health/do-we-have-fewer-hospital-beds-most-europe.

2 Over 21000 covid-19 tests performed in Belarus. 23 March 2020. www.belarus.by/en/presscenter/press-release/over-21000-covid-19-tests-performed-in-belarus_i_0000110202.html.

3 Belarusian company donates 50000 coronavirus tests to Healthcare Ministry. 9 April 2020. www.belarus.by/en/press-center/photo/ti_1658_0000034003.html.

4 Belarus receives 100000 covid-19 rapid tests. 11 May 2020. www.belarus.by/en/press-center/press-release/belarus-receives-100000-covid-19-rapid-tests_i_0000112611.html.

5 Our World in Data. Daily covid-19 tests per thousand people. https://ourworldindata.org/grapher/daily-tests-per-thousand-people-smoothed-7-day?tab=chart\&year=latest\&time=2020-0310.2020-09-03\& country=BLR GBR DEU ITA ESP.

6 В Витебске начали массовое производство тест-систем по выявлению вируса covid-19 [Mass production of test systems to detect covid-19 begins in Vitebsk]. April 2020. http://vitvesti.by/zdorovie/v-vitebske-nachali-massovoe-proizvodstvo-test-sistem-po-vyiavleniiuvirusa-covid-19.html.

732 laboratories in Belarus perform up to 9500 covid-19 tests per day. 2 May 2020 www.tvr.by/eng/news/obshchestvo/32_laboratorii_belarusi_provodyat_do_9500_issledovaniy_v_sutki_na_covid_19_.

8 Our World in Data. Total covid-19 tests. https://ourworldindata.org/grapher/full-list-total-testsfor-covid-19? year=latest\&time=2020-03-03.2020-09-03\& country $=\sim B L R$.

9 Covid-19 Study. https://covid19-survey.org/results.html.

10 WHO. Nursing and elderly home beds per 100 000. https://gateway.euro.who.int/en/indicators/hfa_490-5100-nursing-and-elderly-home-beds-per-100-000/visualizations/\#id=20069.

11 UN Data. Deaths by month of death: Belarus 2019, 2020. http://data.un.org/Data.aspx?q=deaths\%20by\%20month\&d=POP\&f=tableCode\%3a65\%3bcountryCode\%3a112\%3brefYear\%3a2019\%2c2020\&c=2,3,8,13,14\&s=_countryEnglishNameOrderBy:asc,refYear:desc,areaCode:asc\&v=1. 